University of Michigan Law School University of Michigan Law School Scholarship Repository

2015

\title{
Conditional Pricing and Monopolization: a Reflection on the State of Play
}

Daniel A. Crane

University of Michigan Law School, dancrane@umich.edu

Available at: https://repository.law.umich.edu/articles/1844

Follow this and additional works at: https://repository.law.umich.edu/articles

Part of the Antitrust and Trade Regulation Commons, and the Courts Commons

\section{Recommended Citation}

Crane, Daniel A. "Conditional Pricing and Monopolization: a Reflection on the State of Play." Competition L. \& Pol'y Debate 1, no. 1 (2015): 44-9.

This Article is brought to you for free and open access by the Faculty Scholarship at University of Michigan Law School Scholarship Repository. It has been accepted for inclusion in Articles by an authorized administrator of University of Michigan Law School Scholarship Repository. For more information, please contact mlaw.repository@umich.edu. 


\title{
Conditional pricing and monopolization: a reflection on the state of play
}

\author{
Daniel A. Crane \\ Associate Dean for Faculty and Research \\ Frederick Paul Furth, Sr. Professor of Law \\ University of Michigan
}

\author{
counsel: \\ Paul, Weiss, Rifkind, \\ Wharion \& Garrison LLP
}

Conditional pricing practices - including bundled discounting, loyalty rebating, and market share discounts-are not new phenomena in the U.S. market. Their potentially exclusionary consequences were raised in antitrust cases decades ago.' But unlike tying or exclusive dealing — which have a rich history of case law and scholarly coverage-conditional pricing practices did not emerge as salient to the antitrust community until a little over a decade ago. Two federal appellate decisions in the early $2000 \mathrm{~s}$ - Concord Boat ${ }^{2}$ on market share rebates and LePage's ${ }^{3}$ on bundled discountingsparked a period of intensive interest and activity on these topics in the antitrust agencies, courts, bench, and legal and economic academy. Because the U.S. Supreme Court has not yet weighed in (and may not do so in the near future given the small number of antitrust cases it hears), the issues are largely in the hands of the lower federal courts and antitrust agencies, where there is nothing approaching consensus on how to apply Section 2 of the Sherman Act to conditional pricing practices.

In this essay, I propose to provide a high level reflection on the development of the conditional pricing issue over the last decade in the U.S., articulate the current state of play, and speculate

See, e.g., SmithKline Corp. v. EliLilly \& Co., 575 F.2d 1056 (3d Cir. 1978) (finding pharmaceutical company liable under monopolization law for exclusion through bundled discounts).

2 Concord Boat v. Brunswick Corp., 207 F.3d 1039 (8 $8^{\text {th }}$ Cir. 2000) (rejecting claim of boat manufacturers that stern drive engine manufacturer suppressed competition through market share discounts).

3 LePage's, Inc. v. 3M. 324 F.3d 141 (3d Cir. 2003) (en banc) (affirming jury verdict in favor of transparent tape manufacturer claiming that diversified rival harmed competition through use of bundled discounts) about where things may head in coming years. I have been a partisan rather than detached observer in these engagements-representing clients in litigation and writing a number of scholarly papers on the topic, generally in opposition to intrusive antitrust scrutiny of loyalty-enhancing pricing practices. ${ }^{4}$ For purposes of this essay, however, it is not my goal to make the case in favor of conditional pricing or antitrust restraint, but rather to provide a descriptive overview of the continuing course of this debate in the United States.

\section{Finding the Analogue: Disguised Preda- tion or Something Else?}

Federal antitrust law has long been understood to be essentially a common law process, ${ }^{5}$ and the heart of common law reasoning is analogy. It is therefore unsurprising that American lawyers have tended to approach conditional pricing-an area without strong legal precedent-by asking "what known practice is this like?" Of course, analogies are always imperfect (otherwise the analogues would be the same thing) so, assuming that a close analogy to conditional pricing is detected, the question then is whether the rules governing that practice can be imported wholesale or whether they should be modified in some manner.

4 See, e.g., Daniel A. Crane, Bargaining Over Loyalty, 92 Tex. L. Rev. 253 (2013): Can Bundled Discounts Raise Prices Without Excluding Rivals? Comp. Pol. Int'l (Oct. 2009); Mixed Bundling, Profit Sacrifice, and Consumer Welfare, 54 Emory L. J. 423 (2006); Multiproduct Discounting: A Myth of Non-Price Predation, 72 U. Chi. L. Rev. 27 (2005)

5 See, e.g. William F. Baxter, Separation of Powers, Prosecutorial Discretion, and the "Common Law"Nature of Antitrust Law, 60 Tex. L. Rev. 661, 663 (1982); Frank H. Easterbrook, Statutes' Domains, 50 U. Chi. L. Rev. 533، 544 (1983). 
The two early cases of the current era of focusing on conditional pricing came to opposite conclusions on the analogy question. Much of the contestation over the legal treatment of conditional pricing since that time can be understood as playing in the shadows cast by those two early cases-Concord Boat and LePage's.

Concord Boat involved allegations by a number of boat manufacturers that Brunswick, the leading maker of inboard and stern drive marine engines with a market share between $50 \%$ and $75 \%$ depending on the year, monopolized the boat engine market through market share discounts. Between 1984 and 1997, Brunswick offered three tiers of first-dollar discounts-generally $1 \%, 2 \%$, or $3 \%$, but in some years as high as $5 \%$ - to customers who purchased minimum percentages of their requirements-generally ranging from $60 \%$ to $80 \%$ -from Brunswick. Brunswick eventually tried to raise its top tier to $95 \%$, but faced serious backlash from the boat manufacturers and discontinued the market share discount program altogether.

\section{The U.S. Court of Appeals for the Eighth Circuit} rejected the boat builders' claims under Sections 1 and 2 of the Sherman Act. It found that the market share discounts did not substantially foreclose competition, largely based on record evidence suggesting that boat manufacturers were able to switch large percentages of their purchases to alternative suppliers despite the presence of the market share discounts. Significantly, the court also seemed to hold that the market share discounts would be perse legal if they did not cause Brunswick's prices to fall below cost. The court distinguished cases involving bundled discounting and seemingly held that the single-product, abovecost loyalty discounts are lawful on the authority of the U.S.Supreme Court's predatory pricing precedents like Brooke Group and Matsushita. ${ }^{6}$

LePage's involved a market share battle for transparent tape between $3 \mathrm{M}$, a manufacturing conglomerate that sold many different product lines of consumer products through mass merchant retailers, and LePage's, a smaller office supplies manufacturer. $3 \mathrm{M}$ dominated the transparent tape market through its Scotch tape brand with an overall share around $90 \%$, but LePage's was the largest

Brooke Group, Ltd. v. Brown \& Williamson, 509 U.S. 209 (1993); Matsushita Elec. Indus. Co. v. Zenith Radio Corp., 475 U.S. 574 (1986). seller of private label transparent tape, with sales approaching $90 \%$ of that market sub-segment. LePage's sued $3 \mathrm{M}$ for monopolizing the transparent tape market by offering retailers multi-tiered bundled discounts contingent upon purchases across multiple $3 \mathrm{M}$ product lines, including Health Care Products, Home Care Products, Home Improvement Products, Stationery Products (including transparent tape), Retail Auto Products, and Leisure Time.

Unlike the Concord Boat court, the U.S. Court of Appeals for the Third Circuit rejected 3M's argument that its bundled discounts could not be unlawful unless they resulted in below-cost pricing. The court interpreted the Supreme Court's predatory pricing precedents narrowly_as essentially applying only in oligopoly settings or in unconditional price discount circumstances. "Rather than analogizing [bundled discounts] to predatory pricing," the court observed, "they are best compared with tying, whose foreclosure effects are similar."

Although dealing complex factual records and different kinds of contingent discounts, LePage's and Concord Boat offered a stark choice of analogies. Would courts and antitrust authorities approach loyalty rebates as disguised instances of predatory pricing subject to a cost-price test? Or would they reject predatory pricing analogies and roll loyalty discount analysis into an analytical framework similar to the coercion and substantial foreclosure analysis characteristic of exclusive dealing and tying law?

\section{The Rise of the Discount Attribution Test}

Concord Boat did not trigger an immediate reaction in the antitrust community. But LePage's did. The initial reaction to LePage's was overwhelmingly negative. The Solicitor Ceneral of the United States, Justice Department, and Federal Trade Commission recommended that the Supreme Court deny certiorari, but were critical of the opinion, opining that the 'court of appeals' failure to identify the specific factors that made $3 \mathrm{M}$ 's bundled discount anticompetitive may lead to challenges to procompetitive programs and prospectively chill the adoption of such programs." ${ }^{8}$ The case met with

\footnotetext{
324 F.3d at 155.

8 Brief for the United States as Amicus Curiae at 8, 3M Co. v. LePage's Inc., 540 U.S. 807, cert. denied, 124 S. Ct. 2932 (May 28, 2004) (No. 02-1865), http//www.usdoj.gov/atr/cases/f203900/203900.pdf.
} 
extensive scholarly condemnation, including from the highly influential Areeda-Hovenkamp treatise. ${ }^{9}$ And in 2007, the bi-partisan Antitrust Modernization Commission issued a report that was harshly critical of LePage's for failing to provide any clear guidance on when bundled discounts might be condemned as anticompetitive and potentially chilling procompetitive bundled discounts. ${ }^{10}$

At the same time, relatively few commentators advocated applying an unmodified predatory pricing rule to bundled discounts-effectively doing for bundled discounts what Concord Boat did for market share discounts. In the usual common law fashion, many commentators were persuaded that

\section{The LePage's case was initially subject to intense criticism}

predatory pricing was the closest analogy, but not a perfect one. Bundled discounts might exclude equally efficient competitors even though they did not result in predatory pricing. An often-cited example involving shampoo and conditioner developed by Janusz Ordover in Ortho Diagnostics, a bundled discount case in the mid-1990s, was frequently used as an example of how a bundled discount could exclude an equally efficient competitor and still survive the Brooke Croup test for predatory pricing."

The logic of Ortho Diagnostics persuaded many in the antitrust community that predatory pricing law would need some modification before being applied to bundled discounts. A discount attribu-

9 3A Phillip E. Areeda \& Herbert Hovenkamp, Antitrust Law P749, at 305-49 (3d ed. 2008)

10 ANTITRUST MODERNIZATION COMM'N, REPORT AND RECOM MENDATIONS 99 (2007) available at http:// govinfo.library.unt.edu/ amc/report recommendation/amc final_report.pd.

11 Ortho Diagnostic Sys., Inc. v. Abbott Labs., Inc., 920 F. Supp. 455, 467 (S.D.N.Y. 1996) tion test began to gain currency with institutions like the Antitrust Modernization Commission, the Justice Department's Antitrust Division, and many academics. Its high point arrived in 2008 with PeaceHealth, a decision by the U.S. Court of Appeals for the Ninth Circuit adopting the discount attribution test for bundled discounts. ${ }^{12}$ The PeaceHealth court adopted a test requiring that "a plaintiff who challenges a package discount as anticompetitive must prove that, when the full amount of the discounts given by the defendant is allocated to the competitive product or products, the resulting price of the competitive product or products is below the defendant's incremental cost to produce them. ${ }^{{ }^{13}}$ As the court observed, " $[\mathrm{t}]$ his requirement ensures that the only bundled discounts condemned as exclusionary are those that would exclude an equally efficient producer of the competitive product or products. ${ }^{{ }^{14}}$

\section{Intel: Extending PeaceHealth to Market Share Discount}

With PeaceHealth instituting a discount attribution test for bundled discounts with seemingly fairly broad acceptance in the antitrust community, there remained the question of how single-product market share rebates would be analyzed. Would the PeaceHealth logic spill over to market share discounts, or would a pure predatory pricing test, as suggested by Concord Boat, continue to control?

The FTC provided a vague answer in its December 2009 administrative complaint against Intel. Although there were some allegations of bundling across multiple product lines, the core of the Commission's complaint concerned Intel's use of market share discounts to prevent computer OEMs from giving a greater share of their business to Intel's principal rival, ADM. The Commission alleged that Intel's market share discounts resulted in predatory pricing-" purchases that are effectively below cost."15 The Commission did not explain how the "effective" price was computed, but it was widely understood to require a similar analysis to that employed by DC Comp in Provisional Decision against Intel..$^{16}$ That approach requires identifying

\footnotetext{
2 Cascade Health Solutions v. PeaceHealth, 515 F.3d 883 (2008).

13 ld. at 909

14 ld.

5 In re Intel Corp., Complaint, http://www.ftc.gov/sites/default/files/ documents/cases/091216intelcmpt.pdf.

16 Comp 37/990Intel http://ec.europa.eu/competition/sectors/ICT/ intel provisional_decision.pdf.
} 
a non-contestable segment of the market and reallocating all of the discounts that segment to the contestable segment, and then inquiring whether the resulting price in the contestable segment is below the specified measure of cost. In essence, this is performing the PeaceHealth analysis for single-product loyalty discounts.

The Intel matter settled without judicial decision, so there was never any indication as to whether the courts would accept this extension of PeaceHealth to the single-product discount context or continue to insist on a traditional predatory pricing test as suggested in Concord Boat. However, plaintiffs began to use the "contestable/incontestable" model in market share discount cases, on the assumption that courts would be persuaded to apply the PeaceHealth test in this manner. ${ }^{17}$ As of the late years of the last decade, it seemed that the U.S. antitrust community might be settling into at least a tentative agreement on the use of predatory pricing rules--with a discount attribution modification-for all instances of alleged exclusion through conditional pricing.

\section{Discount Attribution Called into Question}

But a consensus position on the discount attribution test would not be so easily achieved. Events in the last few years have exposed the wide rifts that remain in the U.S. antitrust community on the appropriate treatment of conditional pricing.

Two events in 2009 underlined the extent to which broad consensus remained elusive. First, the Obama Justice Department withdrew the Bush Administration's report on monopolization, which had included a proposal to institute the discount attribution test. ${ }^{18}$ Second, Harvard Law Professor Einer Elhauge published an influential article on tying and bundled discounting that sharply countered the academic criticism of LePage's and argued against the use of predatory pricing test for bundled discounts. ${ }^{19}$ Professor Elhauge has since authored a number of additional papers on conditional pricing that argue against predatory pricing rules.

\footnotetext{
17 See, e.g., Eisailnc. v. Sanofi-Aventis U.S., LLC, 2014 WL 1343254 (D. N.J. 2014); In re Intel Microprocessor Litig., 2010 WL 8591815 (D. Del. 2010).

18 Justice Department Withdraws Report on Monopoly Law, http:// www.justice.gov/atr/public/press_releases/2009/245710.htm

19 Einer Elhauge, Tying, Bundled Discounts, and the Death of the Single Monopoly Profic Theory, 123 Harv. L. Rev. 397 (2009).
}

Judicial decisions concerning conditional pricing have been mixed. Several courts have dismissed market share discount cases, finding that the discounts were lawful competition on the merits that did not threaten competition. ${ }^{20}$ However, other courts have rejected the use of predatory pricing rules to address conditional pricing, such as market share discounts, at least in circumstances where the loss of discount could be construed as a "penalty" for disloyalty. ${ }^{21}$

Further, some dissent from the use of predatory pricing analogies and discount attribution rules has arisen from quarters where it might not have been expected. On the milder side, Herbert Hovenkamp-a highly influential scholar and custodian of the Areeda-Turner treatise-recently posted a draft article pointing out the complexities of discount attribution test, particularly in multi-product markets where the goods included in the bundle are purchased in varying proportions. ${ }^{22}$ On the stronger side, FTC Commissioner Josh Wrightone of the most conservative Commissioners in recent FTC memory - gave a speech in 2013 in which he criticized the use of price-cost tests for loyalty discounts and advocated an exclusive dealing approach instead. ${ }^{23}$ Standing alone, Commissioner Wright's comments provide little encouragement to proponents of more aggressive antitrust policing of loyalty discounts, since Josh has made clear that he believes proving harm to competition through exclusive dealing should be a high bar. ${ }^{24}$ Nonetheless, in combination with Professor Hovenkamp's cautions on the use of the discount attribution test and decisions like ZF Meritor, the pendulum seems to have swung somewhat away from the use of predatory pricing rules (modified or otherwise) in the last several years.

20 E.g. Southeast Missouri Hosp. v. C.R. Bard, inc., 642 F.3d $608\left(8^{\text {in }} \mathrm{Cir}\right.$ 2010); Allied Orthopedic Appliances Inc. v. Tyco Health Care Group LP, 592 F.3d 991 (2009).

21 ZF Meritor, LLC v. Eaton Corp., 696 F.3d 254 (3d Cir. 2012).

22 Herbert Hovenkamp, The Areeda-Turner Test for Exclusionary Pricing: A Critical Journal, http://papers.ssin.com/sol3/papers.cfm?abstract id $=2422120$.

23 Joshua D. Wright, Simple but Wrong or Complex but More Accurate? The Case for an Exclusive Dealing-Based Approach to Evaluating Loyalty Discounts, Remarks at the Bates White $10^{\text {th }}$ Annual Antitrust Conference, June 3, 2013, http//www.ftc.gov/public-statements/2013/06/simple-wrong-or-complex-more-accurate-caseexclusive-dealing-based. My debate with Steve Salop about Josh's comments appears at http://truthonthemarket.com/2013/06/09/ wright-is-right-and-wright-is-wrong-a-response-to-steve-salop-on loyalty-discounts/.

24 See In re McWane, Inc., Dissenting Statement of Commissioner Joshua D. Wright, http://www.ftc.gov/system/files/documents/ public_statements/202211/140206mcwanestatement.pdf. 


\section{The 2014 FTC/DOJ Hearings}

On June 23, 2014, the FTC and Justice Department jointly convened a day-long workshop to take the pulse of leading economists and lawyers on the state of knowledge on the competitive effects on conditional pricing practices. ${ }^{25}$ The agencies will likely release a report on the proceedings at some point and I will not attempt to summarize them here, but will provide some informal comments as a participant.

To me, the headline from the day's proceedings was how far the U.S. antitrust community is from any sort of consensus on conditional pricing policies. The views expressed by the panelists ranged from something approaching a presumption of illegality for loyalty-inducing discounts by dominant firms to a safe-harbor for discounts that do not result in below-cost pricing-essentially Concord Boat without the discount attribution qualification. The panelists vigorously contested almost every angle on the topic - whether loyalty discounts are true economic discounts or simply disguised disloyalty penalties; whether conditional discounts can have anticompetitive effects without exclusion by softening competition and facilitating parallel supracompetitive pricing; whether conditional pricing is more similar to predatory pricing or exclusive dealing; whether prohibiting conditional pricing would have hydraulic effects toward more anticompetitive practices such as pure exclusive dealing or vertical integration; whether there are efficiencies attributable to conditional pricing that could not be captured through more competitively benign practices. These, and many other angles, were sharply contested.

It remains to be seen what the agencies make of the workshop and how they use it rhetorically to justify any directions they may seek to pursue. One point that seems clear is that they would have a difficult time claiming the existence of broad consensus on almost any important facet of the current debate. The use of modified predatory pricing rules, once the seemingly anointed course, is now merely one proposal for discussion.

\section{Looking Forward}

We end 2014 with considerable uncertainty about

25 See http//www.ftc.gov/news-events/events-calendar/2014/06/ conditional-pricing-practices-economic-analysis-legal-policy. the future of conditional pricing law in the United States. The possibility of the sort of formal, categorical disapproval of loyalty-inducing pricing by dominant firms reflected in the Ceneral Court's June 12, 2014 decision upholding Intel's liability ${ }^{26}$ seems remote. Yet a wide range of possibilities, including at least an exclusive dealing model, pure predatory pricing rules, or a discount attribution test remain plausible.

In the short term, there is unlikely to be much relief from the uncertainty. The Supreme Court is the only institution practically able to provide a conclusive answer, but it is unlikely to take a major step on conditional pricing until the dust settles. In technical areas like antitrust, the Court often waits for the formation of professional consensus in the relevant field before announcing broad rules. It has rejected a number of petitions for certiorari in conditional pricing cases, probably because the issue was not yet sufficiently crystallized in lower court opinions and expert opinion. Recent events will give the Court little encouragement to act any time soon.

The longer run depends, of course, upon the composition of the Court, the possibility of consensus developing among the antitrust agencies and leading academics, and continuing developments in the lower courts. If anything is predictive, it is the Court's long-term trajectory since the $1980 \mathrm{~s}$ towards protecting unilateral pricing decision from attack unless the pricing is predatory. In upholding the jury's verdict finding liability for loyalty discounting, the ZFMeritor nonetheless court recognized that the force of its earlier LePage's opinion had "been undermined by intervening Supreme Court precedent, ${ }^{27}$ including cases like Weyerhaus$e r^{28}$ on predatory overbidding and linkLine $e^{29}$ on price squeeze. If the Supreme Court stays on its current course, when it finally rules, it will do so in a way that provides event dominant firms a good bit of latitude in offering conditional or loyalty-inducing prices.

\footnotetext{
26 Intel Corp., Case T-286/09, http://curia.europa.eu/juris/document/ document.jsf;jsessionid=9ea7d0f 130 dea92 cbe7378174ebd905893ea6361f8e2.e34Kaxilc3eQc40LaxqMbN4ObhePe0? text $=\&$ docid $=153543 \&$ page $\mid$ nde $=0 \&$ doclang $=E N \&$ mode $=1-$ st\&dir=\&occ $=$ first\&part $=1 \&$ cid $=256025$.

27696 F.3d at 273 n. 11.

28 Weyerhaeuser Co. v. Ross-Simmons Hardwood Lumber Co. 549 U.S 312 (2007).

29 Pac. Bell Tel. Co. v. Linkline Commc'ns, Inc., 555 U.S. 438 (2009).
} 
Finally, a word of strategic advice for those wishing to shape the terms of this debate. For better or for worse, the U.S. debate over the legal treatment of conditional pricing remains driven by the common law's obsession with analogy. Although economists often chafe at the imperfection and over-and under-inclusion of analogies to existing practices, that is the way the courts tend to see the issue. In

\section{For better or worse, the U.S. debate over conditional pricing remains driven by the common law's obsession with analogy}

my opinion, one of the most useful presentations at the FTC/DOJ hearings was Michael Waldman and Michael Whinston's analysis of the claims that the Supreme Court has made about the attributes of price discounting that justify conservative structuring of predatory pricing law and an inquiry into whether conditional pricing practices share those attributes. ${ }^{30}$ Professors Waldman and Whinston identified six such attributes and suggested that conditional discounts do not share the majority of them. ${ }^{31}$ While I disagree with some of their conclusions, this approach is the kind that allows economists to speak influentially to courts on these sorts of challenging questions of economic policy. In my view, future contestation over legal treatment of conditional pricing practices will continue to play in the shadows of the known categories, particularly predatory pricing, tying, and exclusive dealing.

30 Michael Waldman \& Michael Whinston, An Overview of Conditional Pricing Practices, http://www.ftc.gov/system/files/documents/public_events/302251/waldman-whinston.pdf

31 id. ("Need to reduce frivolous litigation;" "Firms need to have a bright line;" "Firms rarely have reasons to price below MC, and its hard to identify above-MC predation (akin to price regulation):" "When $P>M C$, forcing a higher price sacrifices short-run efficiency for speculative long-run gain;" "I $P>M C$, an 'equally efficient competitor' can make sales;" "I $\mathrm{P}>\mathrm{MC}$, a firm whose presence is efficient can make sales.") 